\section{Ikke lett å bli involvert}

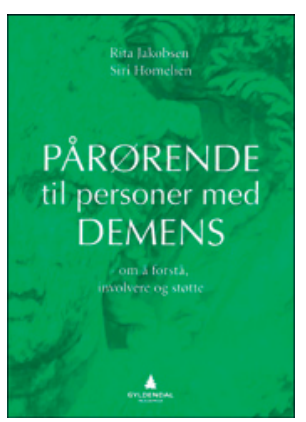

Rita Jakobsen, Siri Homelien

Pårørende til personer med demens

Om å forstå, involvere og støtte. 223 s, tab, ill.

Oslo: Gyldendal Akademisk, 2011.

Pris NOK 269

ISBN 978-82-05-39937-2

Målgruppen er studenter som tar helsefagutdanning på bachelorog masternivå, og helsepersonell som arbeider med personer rammet av demens og deres pårørende.

Layouten er god. Innholdet er delt inn i oversiktlige kapitler med pedagogiske oppsummeringer på slutten av hvert kapittel.

Det bør ikke være vanskelig for vordende helsepersonell innen demensomsorgen å forestille seg at det å være pårørende til en person som får en demenssykdom, kan være vanskelig å takle. $\mathrm{Og}$ at det til tider kan være svært belastende å miste sine nærmeste til denne sykdommen. I de fire første kapitlene blir dette budskapet gjentatt flere ganger uten at leseren nødvendigvis blir noe klokere av den grunn. Ved å tolke elaborerte betraktninger innen mestring, mål, skyldfølelse, samhørighet, kommunikasjon og bemyndigelse, uten å knytte betraktningene mer direkte til yrkesoppgavene til helsepersonell, blir det hele noe utilnærmelig.

Det er forståelig at ressurssterke pårørende med et tettere bånd og et bedre premorbid forhold til den demenssyke, uansett rolle som pårørende, vil mestre utfordringer i hverdagen bedre enn pårørende som selv har skrantende helse, sover dårlig om nettene og har et mindre sosialt nettverk å støtte seg til. Et viktig søkelys forsvinner når forfatterne delvis unngår å ta opp situasjonen knyttet til de mest utsatte pårørende - og belyse hvordan helsepersonell konkret kan hjelpe dem. Å vektlegge respekt, anstendighet og god kommunikasjon hos helsepersonell i møte med personer med demens og deres pårørende, til den generelle grad forfatterne beskriver gjennom flere kapitler - uten å påpeke at dette bør være en selvfølge - gir nærmest inntrykk av at helsepersonell opplever mer byrde ved å yte omsorg og pleie enn det pårørende gjør i sin rolle.

Forfatterne har lang klinisk erfaring innen demensfeltet og burde derfor inkludert mer om den praktiske veiledningen og støtten til pårørende og forankret dette med aktuelle kildehenvisninger. Kapittel 7 om etiske utfordringer er et godt eksempel på hvordan forfatterne lykkes godt med dette. Til en mindre grad lykkes de også i kapittel 5 om pårørende til hjemmeboende personer med demens og i kapittel 6 om pårørende til personer med demens som bor på institusjon. Men dessverre er flere av de første kapitlene for abstrakte for å være til hjelp med å forstå pårørendes situasjon bedre, til tross for at gode sitater fra pårørende ofte er tatt med i kapitlene som et utgangspunkt.

\section{Tor Rosness}

Nasjonalt kompetansesenter for aldring og helse Oslo

\section{Utmerket referanseverk om demens}

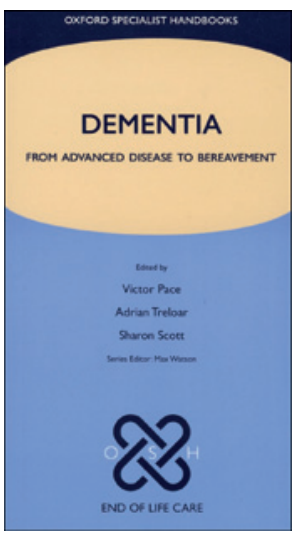

Victor Pace, Adrian Treloar, Sharon Scott, red.

\section{Dementia}

From advanced disease to bereavement, 426 s, tab, ill. Oxford: Oxford University Press, 2011. Pris GBP 38

ISBN 978-0-19-923780-7

Dette er en hendig bok i lommeformat i serien Oxford Specialist Handbooks in End of Life Care. Som for de øvrige bøkene i serien, er formålet å gi praktiske og gode råd og retningslinjer til leger og sykepleiere og andre som arbeider tett opp mot personer med demens og deres pårørende. Retningslinjene og rådene for pasientbehandlingen er basert på oppdatert kunnskap. I forordet legger forfatterne vekt på at dette er kunnskapsbaserte retningslinjer. Hovedvekten er lagt på behandling av pasienter med moderat til alvorlig grad av demens. Således er behandling med antidemenslegemidler kun som en parentes å betrakte.

Dette er ingen tradisjonell lærebok, men den kan brukes som et referanseverk i daglig klinisk arbeid. Stoffet er formidlet i 24 kapitler og strekker seg fra en kort definisjon av demens til å omhandle vurdering av smerte, stress, sorg og akutt somatisk sykdom hos personer med demens. Behandling og tiltak rettet mot komorbid sykdom er godt beskrevet. Det samme gjelder terminal pleie og kommunikasjon med pasienter med alvorlig grad av demens. De pårørendes situasjon er beskrevet i to kapitler, og også her har forfatterne lagt vekt på å formidle praktiske tiltak og hva kan man gjøre for de pårørende for at de skal klare omsorgsoppgavene.

Setningene og avsnittene er korte med greie overskrifter og med bruk av mange kulepunkter, tekstbokser og tabeller. Mange skalaer for vurdering av ulike symptomer er presentert, og forfatterne henviser hyppig til innhold som har relevans for de ulike kapitlene. Leseren må således bla frem og tilbake for å finne nødvendig informasjon. Ved første gjennomlesing virker denne presentasjonsformen litt kaotisk, men man lærer fort å finne frem, og da fungerer denne formidlingsformen godt.

Spesielt vil jeg tro at dette er en nyttig bok for travle leger og sykepleiere som arbeider i sykehjem hvor $80 \%$ av beboerne har symptomer forenlig med en demenssykdom av moderat eller alvorlig grad. Jeg anbefaler den på det varmeste for denne målgruppen, og jeg vil tro at også spesialister i geriatri og alderspsykiatere vil ha glede av den i sin kliniske hverdag.

\section{Knut Engedal}

Nasjonalt kompetansesenter for aldring og helse

Geriatrisk avdeling

Oslo universitetssykehus, Ullevål 